\title{
The Effect of Ownership Structure on Firm Profitability in India: A Panel Data Approach
}

\author{
Nahila Nazir ${ }^{1} \&$ Amarjeet Kaur Malhotra ${ }^{2}$ \\ ${ }^{1}$ Research Scholar, School of Management Studies, Ansal University, Gurgaon, India \\ ${ }^{2}$ Professor and Dean, School of Management Studies, Ansal University, Gurgaon, India \\ Correspondence: Nahila Nazir, School of Management Studies, Ansal University, Gurgaon, India. E-mail: \\ bhatnahila@gmail.com
}

Received: February 26, 2016

Accepted: March 30, 2016

Online Published: May 25, 2016

doi:10.5539/ijef.v8n6p237

URL: http://dx.doi.org/10.5539/ijef.v8n6p237

\begin{abstract}
This paper attempts to analyze whether there is solid evidence to support the idea that variations across firms in observed ownership structures lead to systematic variations in observed firm performance. The current study examines this hypothesis by evaluating the impact of the ownership structure on corporate performance, measured by profitability, using data of BSE 100 Index companies. This study design ownership structure, first, as an exogenous variable and, second; we take into account four different measures of ownership structure showing different groups of shareholders with conflicting interests. Using panel data regression model in between all ownership structure measures and profitability measures, the empirical findings suggest that the non-promoters holding and non-promoters non institutional holding have a significant impact on EPS of the firm. In case of promoters holding and non-promoters institutional holding no effect is found on EPS of the firm. And in case of ROI promoters holding, non-promoters institutional holding and non-promoters non institutional holding have a significant impact on ROI of the firm. In case when non-promoters holding is taken as individual measure no effect is found on ROI of the firm. Further in case of PAT, it is found that the non-promoters holding and non-promoters non-institutional holding have a significant impact on PAT of the firm. In case of promoters holding and non-promoter institutional holding no effect is found on PAT of the firm. Presence of concentrated ownership is found in Indian firms.
\end{abstract}

Keywords: ownership structure, firm performance, earning per share, return on investment, profit after tax, India

\section{Introduction}

Corporate governance is a very popular research area because it affects many different corporate decisions and behaviors. It covers various topics and one of them is ownership structure. La Porta, Lopez-de-Silanes, Shleifer, and Vishny (1997, 1998, 1999, 2000), provide evidence that the laws of corporate governance and their execution are important factors in financial market development, firm value, and investor protection. Ownership structure, being a system within corporate governance in order to accomplish improved performance of a firm has been considered to influence firm performance for many years. For instance, Adam Smith (1776) highlights that joint-stock companies tend to be less effective compared to private co-partner firms considering that the directors would not watch around 'other people's money' with 'the similar anxious vigilance' as their own.

Ownership structure is defined by the distribution of equity regarding votes and capital but in addition to the identity of the equity owners. The incentives associated with managers are generally based on these types of structures and also handle the economic efficiency of corporations. There are two main dimensions of ownership structure i.e. ownership concentration and owner identity. La Porta et al. (1996, 1997 and 1998) argue that ownership concentration and institutional differences are a response to differing degrees of legal protection of minority shareholders across countries. Claessens at al. (2002) show a link between corporate governance and firm valuation. In their paper, they argue that higher ownership concentration of the controlling shareholder affects market value of firm positively, but higher divergence between cash flow rights and voting rights lowers market valuation. As far as identity is concerned, Jensen (1990) and Cui (2002) found positive effect of managerial ownership on firm performance. The modern diverse ownership corporation has busted the connection between ownership and active management of the organization. These companies are managed by professional managers who normally own merely a small portion of the shares. To be able to demonstrate using 
the impact associated with ownership concentration on the corporate performance, the result has contradicting conclusions coming from former studies. Shleifer (1986) and Agrawal (1996) found positive effect of high concentration; Hingley (1970), and Pedersen (1999) found the effect to be negative. Some other studies related to owner identities and firm performance also have contradicting results. Morck et al. (1988) found the effect to be negative and argued the existence of managerial entrenchment. Another main issue on which there is a continuing discussion in the literature is 'the effect and advantage of the separation of ownership and control'. Early theorists such as Williamson (1964) suggest that non-owner managers choose their very own interests more than that of the investors. Consequently, non-owner managed company's turn out to be less successful compared to owner-managed corporations.

\subsection{Aim of the Study}

The aim and objective of this study is to test the impact of ownership structure on firm's profitability in Indian firms. This study investigates whether there is evidence to support the notion that variations across firms in observed ownership structures result in systematic variations in observed firm performance in the context of Indian firms. The current study examines this hypothesis by assessing the impact of the structure of ownership on firm performance measured by profitability ratios using data of BSE 100 Index from 2000-2014, covering all major sectors. This study uses three basic measures of profitbility - namely, Earning per share, return on investment and profit after tax - and consider two major measures of ownership - namely, promoters holding and non-promoters holding then subdivided non promoter holding into two categories namely non promoter institutional holding and non-promoter non institutional holding. The study will employ multiple regression models in establishing the relation between the said variables. The paper is primarily motivated because of lack of evidence in this regard as the literature review shows a scattered and scanty picture on this aspect and no consolidated work was found in India hence this research.

\subsection{Objectives of the Study}

1) To analyze the impact of ownership structure on firm's performance.

2) To analyze the ownership structure of the selected firms in India.

\subsection{Contribution}

This study contributes to the body of knowledge in the area of corporate governance taking ownership structure as an issue with a special reference to Indian market. It looks at the effectiveness of ownership structure in controlling profitability of Indian firms. The impact of ownership structure on firm performance has been widely tackled in various developed markets and more recently in emerging markets, but was less discussed before, in India in recent changing environment. The research work done earlier have only taken few ownership structure aspects into account while this study has taken four aspects listed above and presents a broader view of ownership structure. Additionally the study provides feedback to investors with respect to effectiveness of the returns and the subsequent course of action required ensuring the good use of their money that will boost investor confidence and increase investment and economic activities in the India. The structure of ownership of Indian firms has not been studied extensively, nor has its impact on performance been assessed on larger level. This paper tries to fill these gaps.

\subsection{Literature Review}

The relationship between ownership structure and firm performance has acquired significant attention. Berle and Means (1932) are the pioneers to bring focus to the idea that with the improved diffuseness of the ownership structure, the firm performance deteriorates. Demsetz (1983) applies a counter argument by noticing that it is not reasonable to guess that the diffused ownership structure dilutes profit maximization target as a guide pertaining to resource allocation and utilization. He argues how the ownership structure is an 'endogenous' factor for making the most of the profit as well as worth of a corporate enterprise. When the requirement of capital is huge for accomplishing scale quickly, you will find there's need to fulfill the requirement (of capital) by generating offer to the public at large to bring about the equity share capital of a company. Subscription by the members of general public towards the equity share capital of a company contributes to diffusion of ownership structure. Therefore, the value advancement of a business organization by attaining scale requires a diffused ownership structure, as single ownership is not sufficient to increase the value of a firm.

Going with the above-stated arguments as well as counter arguments, several empirical reports are already undertaken in several nations; however no general opinion has been achieved. Lauterbach B and Vaninsky A (1999) found that owner manager firms are productive in bringing in net income compared to companies managed by a professional manager, and family firms run by their owners perform (relatively) the toughest. 
Loderer and Martin (1997) had taken shareholding by the insiders (i.e., director's ownership) to be a way of measuring ownership. Using the stated measure as endogenous variable and Tobin's $Q$ as profitability measure, they observed (through simultaneous equation model) that ownership isn't going to anticipate performance but performance can be an unfavorable predictor of ownership. Cho (1998) found that company performance has an impact on ownership structure but not vice versa. Demsetz and Villalonga (2001) researched the relationship relating to the ownership structure and also the performance they found no considerable organized relation between ownership structure and firm performance. Welch (2003), implementing the model of Demsetz and Villalonga (2001), analyzed the relationship involving ownership structure and firm performance of Australian listed companies. Her OLS outcomes claim that ownership of shares from the top management is actually significant in describing the performance assessed by accounting rate of return, however, not significant if performance is calculated by Tobin's Q. On the other hand, as soon as ownership is treated as endogenous, the same is not influenced by any of the performance measures. Kapopoulos and Lazaretou (2007) experimented with the model of of Demsetz and Villalonga (2001) with regard to 175 Greek companies for the year 2000 and observed better company profitability demands less diffused ownership structure.

Mei Yu (2013) found that a higher degree of state ownership is superior to a dispersed ownership structure because of the benefits of government support and political associations. While as in the Indian market, Srivastava (2011) found existence of highly concentrated ownership structure. He further conclude that the dispersed ownership percentage affects performance indicators but not stock market performance indicators, which suggest that there might be some other factors affecting firms performance other than ownership structure. An inverted u-shaped relationship of ownership concentration and firm performance for firms that operate in non-EU-member countries as well as those firms that are situated in less developed institutional systems is found by Benjamin and Czarnitzki (2015).

Kumar (2004) conclude that the foreign shareholding pattern does not influence the firm performance overall performance significantly. In addition they document that institutional shareholders especially the development financial institutions and the directors" have an effect on firm performance positively once their ownership crosses a threshold level. This is consistent with the fact that many Indian corporate are family dominated enterprises. Their results further document that ownership variable isn't endogenous. Michael and Eric (2008) discovered that freestanding family owned businesses organizations with a single share class have equivalent market performance than other businesses organizations based on Tobin's q ratios, excellent accounting performance based on ROA. Ersoy (2015) found that the concentration of the large shares of companies one or a few shareholders has a negative effect on related firm's performance. They further demonstrated that large shareholders and concentrated ownership of the firms would actually lead to different financial performances. Mohamed (2009) present the data of interdependencies between the board and ownership structures. Their results recommend that the banks substitute between governance mechanisms that align the interests of managers and shareholders. So there are mixed results on impact of ownership structure worldwide. This paper brings together several facets of corporate finance and firm performance and investigates whether variations across firms in observed ownership structures cause systematic variations in observed firm performance in the context of Indian firms.

\subsection{Hypothesis to Be Tested}

$\mathrm{H}_{01}$ : There is no impact of ownership structure on earning per share.

$\mathrm{H}_{1}$ : There exists significant impact of ownership structure on earning per share.

$\mathrm{H}_{02}$ : There is no impact of ownership structure on return on investment.

$\mathrm{H}_{2}$ : There exists significant impact of Ownership structure on return on investment.

$\mathrm{H}_{03}$ : There is no impact of ownership structure on profit after tax.

$\mathrm{H}_{3}$ : There exists significant impact of Ownership structure on profit after tax.

\section{Data Collection, Research Methodology and Variables Used in the Study}

\subsection{Sample Collection}

The study uses the BSE 100 Index companies provided by the Bombay Stock Exchange as the sample. The list consists of 100 companies. All the data used is secondary in nature. This study collect and derive accounting ratios used in the study that is Earning Per Share, Return on Investment and Profit after Tax, and ownership structure measures such as promoters, non-promoters, non-promoters institutional and non-promoter non institutional shareholding data from 'Prowess' data base of the Centre for Monitoring Indian Economy (CMIE) 
for the period of 15 years starting from 2000-2014.

\subsection{Method}

\subsubsection{Descriptive Analysis}

In the research study, the secondary data of different variables related to ownership structure and firm profitability in the BSE 100-Index is used. The data is collected from the different source as mentioned in above section. The descriptive analysis of the variables is done and represented. In descriptive analysis of the variables, the measure of central tendency, mean and distribution are estimated.

\subsubsection{Panel Data Regression Model}

Panel data is data that involves measurements of many individual units over a period of time, i.e., the same cross-sectional unit is surveyed over time. In short, panel data has the space and time dimensions. In the study the time series data of different variables related to Ownership structure, firm's performance of the companies in the Index BSE-100 is used. Hence the nature of the data is panel. In order to analyze the panel data, the fixed and random effect model is applied in the study. The panel data regression model can be represented as:

$$
Y_{i t}=\beta_{i}+\beta_{1} X_{\text {lit }}+\beta_{2} X_{2 i t}+\beta k X k i t+u i t
$$

The subscript $i$ indicate the cross-sections considered in the study and t represents the time series behavior of the variables. The choice of fixed effect model and random effect model depends on the results of $\mathrm{f}$ test as well as Hausman test.

\subsection{Variables Used in the Study}

\subsubsection{Firm Performance}

A perennial query that affected the earlier research studies regarding ownership and performance is really in respect to the selection of way of measuring performance. Should it be accounting rate of return or EPS or market-based return or others? Demsetz and Lehn (1985) applied accounting rate of return, while Demsetz and Villalonga (2001) used Tobin's Q as proxy for the market-based performance. Previously researchers assessed firm performance sometimes by accounting rate of return or Tobin's Q. A number of studies applied both equally. Both measures possess shortcomings. Following Joh (2003), this study used accounting profitability as measures of firm performance. Accounting profitability measures have various advantages. First of all, using the stock returns for firm value might mislead the true firm value when the stock market is inefficient due to direct or indirect regulations which doesn't necessarily impact each and every firm. Most developing countries exhibit stock market inefficiency. Second, as pointed out Mossman et al. (1998), a firm's financial survivability is directly associated with its accounting profitability rather than its stock market value. In this study the basic profitability ratios such as Earnings per Share, Return on Investment and Profit after Tax are used to measure the profitability of the firms.

\subsubsection{Ownership Structure}

Demsetz (1983) and Demsetz and Lehn (1985), and the like have noted that endogeneity of ownership structure must be accounted for whenever analyzing the impact ownership structure has on firm profitability. The work by Demsetz and Villalonga (2001) is inspired by the necessity to re-examine the relationship between ownership structure and firm performance considering not just the endogenity issue but in addition various other dimensions of ownership structures. Particularly these people suggest the portion of shares possessed by outside shareholders as well as by management needs to be assessed individually since they reflect various categories of individuals who may have different interests. In this research study the annual data of different Ownership Structure measures are selected for 15 years (2000-2014). Ownership structure of selected firms is expressed by four different aspects which are promoters holding, non-promoters holding, non-promoter institutional holding and non-promoter non institutional holding. Impact of all the measures of ownership structure is shown on different profitability measures.

We model ownership structure, first, as an exogenous variable and, second, we examine different measures of ownership structure: (a) promoters, (b) non-promoters, (c) non-promoters institutional, and (d) non-promoters non institutional holding and to study firm performance, basic profitability ratios have been taken as performance measures. The relationship between corporate performance and ownership structure tend to exist, because ownership concentration and owner identity impacts the incentives of each and every party inside the firm, and thus have an effect on the firm's capability to solve agency problems. 


\section{Empirical Results}

\subsection{Descriptive Analysis}

In this research study the annual data of the different profitability measures are selected for 15 years (2000-2014) in order to analyze the performance of selected firms. Measures for profitability taken are earning per share (EPS), return on investment (ROI) and profit after tax (PAT).

\subsubsection{EPS}

The average EPS of the firms are calculated. EPS is considered to be the single most popular, widely used financial performance benchmark of all (Graham et al.) surveyed 400 financial executives in the US and reported that the majority, by far, were of the opinion that earnings were the most important performance measure they report to outsiders.

The results indicate that the MRF Ltd. is having the highest average EPS of (Rs.594.97) in last 15 years followed by Laxmi Machine Works Ltd. (Rs.272.97) and Bosch Ltd. (Rs.256.57). In the BSE 100 firms only three firms are found to have negative EPS, these firms are Piramal Enterprise Ltd. (Rs.-0.46), Essar Oil Ltd. (Rs.-0.47) and IFCI Ltd. (Rs.-2.47). The companies with lowest positive EPS are Arvind Ltd (Rs.1.13), Mangalore Refinery \& Petrochemicals Ltd. (Rs.1.4467) and Jain Irrigation Systems Ltd. (Rs.4.33).

In the study a frequency distribution of the companies is done on the basis of EPS. The frequency distribution is shown below in Table 1 .

Table 1. Frequency distribution of firms w.r.t average EPS for the period 2000-2014

\begin{tabular}{ccc}
\hline Average EPS & Frequency & Percent \\
\hline less than Rs 10 & 21 & $21.0 \%$ \\
Rs 10 - Rs 20 & 25 & $25.0 \%$ \\
Rs 20 - Rs 30 & 14 & $14.0 \%$ \\
Rs 30 - Rs 50 & 21 & $21.0 \%$ \\
More than Rs 50 & 19 & $19.0 \%$ \\
Total & 100 & 100.0 \\
\hline
\end{tabular}

The results indicate that 19 percent of firms in BSE 100 Index are having Average EPS more than Rs 50, 21 percent of the firms are having average EPS in the range of Rs $30-50,14$ percent of the firms are found to have average EPS of Rs 20-30, 25 percent of firms are found to have average EPS in the range of Rs 10-20 and 21 percent of the firms are having the EPS Less than Rs 10.

\subsubsection{ROI}

Return on investment (ROI) is the profit for the investor coming from an investment. A performance strategy used to evaluate the efficiency of expenditure or to compare the efficiency of other investments. ROI measures the amount of return on an investment relative to the investment's cost.

The results indicate that the Hindustan Unilever Ltd. is having the highest average ROI of ( 82.77 percent) in last 15 years followed by Nestle India Ltd. (81.93 percent) and Colgate-Palmolive (India) Ltd. (76.30 percent). In the BSE100 firms only three firms are found to have negative three, these firms are Arvind Ltd. (-3.89 percent), I F C I Ltd. (-4.58 percent) and Essar Oil Ltd. (-9.53 percent). The companies with lowest positive ROI are Mangalore Refinery \& Petrochemicals Ltd. (2.002 percent), Max India Ltd. (2.21 percent) and Ranbaxy Laboratories Ltd. [Merged] (2.45 percent).

In the study a frequency distribution of the companies is done on the basis of ROI. The frequency distribution is shown below in Table 2 .

Table 2. Frequency distribution of firms w.r.t average ROI for the period 2000-2014

\begin{tabular}{ccc}
\hline Average ROI & Frequency & Percent \\
\hline less than $10 \%$ & 17 & $17.00 \%$ \\
$10-20 \%$ & 42 & $42.00 \%$ \\
$20-30 \%$ & 25 & $25.00 \%$ \\
$30-40 \%$ & 11 & $11.00 \%$ \\
more than $40 \%$ & 5 & $5.00 \%$ \\
Total & 100 & $100.00 \%$ \\
\hline
\end{tabular}


The results indicate that 5 percent of firms in BSE 100 index are having average ROI more than 40 percent, 11 percent of the firms are having average ROI in the range of $30-40$ percent, 25 percent of the firms are found to have average ROI of 20-30 percent, 42 percent of firms are found to have average ROI in the range of 10-20 percent and 17 percent of the firms are having the ROI less than 10 percent.

\subsubsection{PAT}

Profit is an income distributed to the owner in a profitable market production process (business). Profit is a measure of profitability which is the owner's major interest in income formation process of market production. The net amount earned by a business after all taxation related expenses have been deducted. The profit after tax is often a better assessment of what a business is really earning and hence can use in its operations than its total revenues.

The results indicate that the Oil \& Natural Gas Corpn. Ltd.is having the highest average PAT of (Rs14264.64 cr.) in last 15 years followed by Reliance Industries Ltd. (Rs.12032.15 cr.) and State Bank Of India (Rs.6407.35 cr.). In the BSE100 firms only one firm is found to have negative PAT, and that firm is Essar Oil Ltd. (Rs.-211.09 cr.). The companies with lowest positive PAT are I F C I Ltd. (Rs.5.83 cr.), Satyam Computer Services Ltd. [Merged] (Rs.9.739 cr.) and Ranbaxy Laboratories Ltd. [Merged] (Rs.16.34cr.).

In the study a frequency distribution of the companies is done on the basis of PAT. The frequency distribution is shown below in Table 3.

Table 3. Frequency distribution of firms w.r.t average PAT for the period 2000-2014

\begin{tabular}{ccc}
\hline Average PAT & Frequency & Percent \\
\hline less than Rs 50 Cr. & 9 & $9.00 \%$ \\
Rs 50 - 200 Cr. & 30 & $30.00 \%$ \\
Rs 200 - 500 Cr. & 26 & $26.00 \%$ \\
Rs 500 - 1000 Cr. & 17 & $17.00 \%$ \\
More than Rs 1000 Cr. & 18 & $18.00 \%$ \\
Total & 100 & $100.00 \%$ \\
\hline
\end{tabular}

The results indicate that 18 percent of firms in BSE 100 Index are having average PAT of more than rs $1000 \mathrm{cr}$, 17 percent of the firms are having average PAT in the range of rs. $500-1000$ cr., 26 percent of the firms are found to have average PAT of rs. $200-500 \mathrm{cr}$., 30 percent of firms are found to have average PAT in the range of rs 50-200 cr. and 9 percent of the firms are having the average PAT less than rs. $50 \mathrm{cr}$.

\subsubsection{Promoters Holding}

In the research study the annual data of different Ownership Structure measures are selected for 15 years (2000-2014). Ownership structure of selected firms is expressed by four different aspects which are promoters holding, non-promoters holding, (subdivided into two more categories non-promoter institutional holding and non-promoter non-institutional holding).

The results indicate that the Mangalore Refinery \& Petrochemicals Ltd. is having the highest average promoters holding of (85.15 percent) in last 15 years followed by Steel Authority Of India Ltd. (84.98 percent), and Godrej Industries Ltd. (80.29 percent). The companies having no promoters holding are Larsen \& Toubro Ltd., Housing Development Finance Corpn. Ltd. and Federal Bank Ltd. The companies with lowest percentage of promoters holding are Infosys Ltd. (20.26 percent), H D F C Bank Ltd. (23.24 percent), and Grasim Industries Ltd. (23.80 percent).

In the study a frequency distribution of the companies is done on the basis of promoters holding. The frequency distribution is shown below in Table 4.

Table 4. Frequency distribution of firms w.r.t average promoters holding for the period 2000-2014

\begin{tabular}{ccc}
\hline Average Promoters Holding & Frequency & Percent \\
\hline less than $10 \%$ & 3 & $3.00 \%$ \\
$10-30 \%$ & 16 & $16.00 \%$ \\
$30-50 \%$ & 39 & $39.00 \%$ \\
$50-70 \%$ & 33 & $33.00 \%$ \\
more than $70 \%$ & 9 & $9.00 \%$ \\
Total & 100 & $100.00 \%$ \\
\hline
\end{tabular}


The results indicate that 9 percent of firms in BSE 100 index are having average promoters holding of more than 70 percent, 33 percent of the firms are having average promoters holding in the range of $50-70$ percent of holding, 39 percent of the firms are found to have average promoters holding of $30-50$ percent of holding, 16 percent of firms are found to have average promoters holding in the range of $10-30$ percent of holding and 3 percent of the firms are having the average promoters holding less than less than 10 percent of holding.

\subsubsection{Non Promoters Holding}

The results indicate that the Housing Development Finance Corpn. Ltd.is having the highest non promoters holding of (100 percent) in last 15 years followed by Larsen \& Toubro Ltd. (98.20 percent), and Federal Bank Ltd. (97.04 percent). The companies with lowest percentage of non-promoters holding are Mangalore Refinery \& Petrochemicals Ltd. (14.85 percent), Steel Authority Of India Ltd.(15.0014 percent).and Godrej Industries Ltd. (19.7 percent).

In the study a frequency distribution of the companies is done on the basis of non-promoters holding. The frequency distribution is shown below in Table 5.

Table 5. Frequency distribution of firms w.r.t average non- promoters holding for the period of 2000-2014

\begin{tabular}{ccc}
\hline Average Non-Promoters Holding & Frequency & Percent \\
\hline $10-30 \%$ & 10 & $10.00 \%$ \\
$30-50 \%$ & 33 & $33.00 \%$ \\
$50-70 \%$ & 42 & $42.00 \%$ \\
more than $70 \%$ & 15 & $15.00 \%$ \\
Total & 100 & $100.00 \%$ \\
\hline
\end{tabular}

The results indicate that 15 percent of firms in BSE 100 index are having average non-promoters holding of more than 70 percent of holding, 42 percent of the firms are having average non-promoters holding in the range of 50 - 70 percent of holding, 33 percent of the firms are found to have average non-promoters holding of $30-50$ percent of holding, 10 percent of firms are found to have average non-promoters holding in the range of $10-30$ percent of holding.

\subsubsection{Non Promoters Institutional Holding}

The results indicate that the I D B I Bank Ltd. is having the highest average Non Promoters Institutional Holding of (77.097 percent) in last 15 years followed by Mahindra\& Mahindra Ltd. (49.68 percent), and Federal Bank Ltd. (49.30 percent). The companies with lowest percentage of non-promoters institutional holding are Mangalore Refinery \& Petrochemicals Ltd. (3.45 percent), Essar Oil Ltd. (5.997 percent) and Godrej Industries Ltd. (6.11 percent).

In the study a Frequency Distribution of the Companies is done on the basis of Non Promoters Institutional Holding. The frequency distribution is shown below in Table 6 .

Table 6. Frequency distribution of firms w.r.t average promoters holding for the period 2000-2014

\begin{tabular}{ccc}
\hline Average Non-Promoter Institutional & Frequency & Percent \\
\hline less than $10 \%$ & 4 & $4.00 \%$ \\
$10-20 \%$ & 23 & $23.00 \%$ \\
$20-30 \%$ & 35 & $35.00 \%$ \\
$30-40 \%$ & 29 & $29.00 \%$ \\
$40-50 \%$ & 8 & $8.00 \%$ \\
more than 50\% & 1 & $1.00 \%$ \\
Total & 100 & $100.00 \%$ \\
\hline
\end{tabular}

The results indicate that only 1 percent of firms in BSE 100 index are having average non-promoters institutional holding of more than 50 percent of holding, 37 percent of the firms are having average non-promoters institutional holding in the range of $30-50$ percent of holding, 35 percent of the firms are found to have average non-promoters institutional holding of 20 - 30 percent of holding, 23 percent of firms are found to have average non-promoters institutional holding in the range of $10-20$ percent of holding and 4 percent of the firms are 
having the average non promoters institutional holding less than 10 percent of holding.

\subsubsection{Non Promoters Non Institutional Holding}

The results indicate that the M R F Ltd. is having the highest average non promoters non institutional holding of (58.06 percent) in last 15 years followed by Federal Bank Ltd. (47.73 percent), and Tata Elxsi Ltd. (47.19 percent). The companies with lowest percentage of non-promoters non institutional holding are Bharat Heavy Electricals Ltd. (4.297 percent), Bharat Electronics Ltd. (6.87 percent) and Dabur India Ltd. (8.08 percent).

In the study a frequency distribution of the companies is done on the basis of promoters holding. The frequency distribution is shown below in Table 7.

Table 7. Frequency distribution of firms w.r.t average non promoter non institutional holding for the period 2000-2014

\begin{tabular}{ccc}
\hline Average Non Promoter Non Institutional Holding & Frequency & Percent \\
\hline less than $10 \%$ & 5 & $5.00 \%$ \\
$10-20 \%$ & 24 & $24.00 \%$ \\
$20-30 \%$ & 42 & $42.00 \%$ \\
$30-50 \%$ & 28 & $28.00 \%$ \\
more than 50\% & 1 & $1.00 \%$ \\
Total & 100 & $100.00 \%$ \\
\hline
\end{tabular}

The results indicate that only 1 percent of firms in BSE 100 Index are having average non-promoters non institutional holding of more than 50 percent of holding, 28 percent of the firms are having average non-promoters non institutional holding in the range of 30 - 50 percent of holding, 42 percent of the firms are found to have average non-promoters non institutional holding of 20 - 30 percent of holding, 24 percent of firms are found to have average non-promoters non institutional holding in the range of $10-20$ percent of holding and 5 percent of the firms are having the average non promoters non institutional holding less than 10 percent of holding.

\subsection{Panel Data Regression Model}

In the case of pooled regression model, it is assumed that all firms are homogenous and there is no impact of time on the EPS, ROI and PAT of the firms. Hence in pooled regression model, the data is assumed to be cross sectional in nature. However, the data collected in the research study is panel data because the data of selected variables are collected for 100 firms in BSE 100 Index for the period of 2000-2014. Hence the panel regression model is applied to analyze the impact of ownership structure on the firms on the profitability.

In panel data regression model two popular tests are available, fixed effect model and random effect model. The fixed effect model assumes that the firms are heterogeneous in nature. However the random effect model is applied to get generalized results assuming that firms in the sample are randomly selected. Statistically f-test and hausman test is used to identify the most suitable panel regression model to be applied in the study and the results are interpreted accordingly. The results of f-test and hausman test are shown below

Table 8. F-test and Hausman test results for performance measured by earning per share w.r.t ownership structure measures

\begin{tabular}{ccccc}
\hline Dependent Variable & Independent variable & $\mathrm{f}$ test $(\mathrm{p}$ value) & Hausman test (p value) & Panel data regression model to be applied \\
\hline & Promoters holding & 10.23 & 3.241 & Random Effect model \\
& & $(.000)$ & $(.071)$ & Fixed effect model \\
& Non promoters & 10.745 & $\mathbf{4 . 3 7 5}$ & \\
& holding & $(.000)$ & $\mathbf{( . 0 3 6 5})$ & Random Effect model \\
Earnings Per share & Non promoters & 10.777 & .155 & Fixed Effect Model \\
& Institutional & $(.000)$ & $(.693)$ & \\
\hline
\end{tabular}

The results of f-test indicate that the probability value of f-statistic is less than $5 \%$ level of significance. Hence with $95 \%$ of confidence level it can be concluded that the fixed effect model is significantly better than pooled 
regression model. However, the hausman test indicates that the probability value is less than $5 \%$ level of significance in case of non-promoters holding as well as non-promoters non institutional holding and in case of promoters holding and non-promoters institutional holding the probability value is not less than $5 \%$ level of significance. Hence the null hypothesis that the effects are random cannot be accepted in case of non-promoters holding as well as non-promoters non institutional holding and it can be concluded that fixed effect model is suitable to apply for analysis. And in case of promoters holding and non-promoters institutional holding random effect model is suitable to apply for analysis.

Table 9. F-test and Hausman test results for performance measured by return on investment w.r.t ownership structure measures

\begin{tabular}{ccccc}
\hline Dependent Variable & Independent variable & $\mathrm{f}$ test $(\mathrm{p}$ value) & Hausman test (p value) & Panel data regression model to be applied \\
\hline & Promoters holding & 9.37 & 0.0507 & Random Effect Model \\
& & $(.000)$ & $(.8217)$ & \\
& Non promoters & 7.82 & 0.826 & Random Effect Model \\
Return on & holding & $(.000)$ & $(.363)$ & Fixed Effect Model \\
Investment & Non promoters & 8.277 & $\mathbf{5 . 0 6 2}$ & \\
& Institutional & $(.000)$ & $\mathbf{( . 0 2 4})$ & Random Effect Model \\
& Non promoters non & 7.82 & .102 & \\
\hline
\end{tabular}

The results of f-test indicate that the probability value of f-statistic is less than $5 \%$ level of significance. Hence with $95 \%$ of confidence level it can be concluded that the fixed effect model is significantly better than pooled regression model. However, the hausman test indicates that the probability value is less than $5 \%$ level of significance in case of non-promoters institutional holding and in case of promoters holding and non-promoters institutional holding and non-promoters non institutional the probability value is not less than 5\% level of significance. Hence the null hypothesis that the effects are random cannot be accepted in case non promoters' institutional holding and it can be concluded that fixed effect model is suitable to apply for analysis. And in case of promoters holding, non-promoters holding and non-promoters non-institutional holding random effect model is suitable to apply for analysis.

Table 10. F-test and Hausman test results for performance measured by profit after tax w.r.t ownership structure measures

\begin{tabular}{ccccc}
\hline Dependent Variable & Independent variable & $\mathrm{f}$ test ( $\mathrm{p}$ value) & Hausman test ( $\mathrm{p}$ value) & Panel data regression model to be applied \\
\hline & Promoters holding & 35.95 & 3.190 & Random Effect Model \\
& & $(.000)$ & $(.071)$ & Random Effect Model \\
& Non promoters & 34.34 & .165 & \\
Profit after Tax & holding & $(.000)$ & $(.684)$ & Random Effect Model \\
& Non promoters & 34.28 & .0081 & Random Effect Model \\
& Institutional & $(.000)$ & $(.927)$ & .578 \\
\hline
\end{tabular}

The results of f-test indicate that the probability value of f-statistic is less than $5 \%$ level of significance. Hence with $95 \%$ of confidence level it can be concluded that the fixed effect model is significantly better than pooled regression model. However, the hausman test indicates that the probability value is not less than $5 \%$ level of significance in every variable in study i.e., promoters holding, non-promoters holding, non-promoters institutional and non-promoters non institutional. Hence the null hypothesis that the effects are random cannot be accepted in any variable in study and it can be concluded that random effect model is suitable to apply for analysis.

\subsubsection{Panel Regression Model}

In order to analyze the impact of ownership in the selected companies on EPS, ROI and PAT of the firms, the fixed effect model and random effect model is applied. In the analysis the EPS, ROI and PAT are considered as dependent variable however the different aspects of ownership structures are considered as independent variables. 
The fixed effect model is applied with EPS as dependent variable and non-promoter holding and non-promoter non institutional holding as ownership structure in the firms as independent variable. However, random effect model is applied in case of promoters holding and non-promoter institutional holding. The result of the panel regression model is shown below in Table 11.

Table 11. Impact of ownership structure of the firms on EPS

\begin{tabular}{|c|c|c|c|c|c|c|}
\hline $\begin{array}{l}\text { Panel regression } \\
\text { model }\end{array}$ & Independent variable & \multicolumn{2}{|c|}{ Regression coefficients } & $\begin{array}{c}\text { T statistics } \\
\text { ( } \mathrm{p} \text { value })\end{array}$ & \multirow{2}{*}{$\frac{\text { F statistics }}{\text { (p value) }}$} & $\mathrm{R}$ square \\
\hline \multirow{3}{*}{$\begin{array}{c}\text { Random Effect } \\
\text { Model }\end{array}$} & \multirow{3}{*}{ Promoters Holding } & Intercent & & & & \multirow{3}{*}{$-.169 \%$} \\
\hline & & $\begin{array}{c}\text { Intercept } \\
\text { Alpha }\end{array}$ & 38.36 & $\begin{array}{c}2.469 \\
(.0136)\end{array}$ & .0573 & \\
\hline & & Beta & .069 & $\begin{array}{l}.239 \\
(.810)\end{array}$ & $(.810)$ & \\
\hline \multirow[t]{2}{*}{ Fixed Effect Model } & \multirow{2}{*}{$\begin{array}{c}\text { Non Promoters } \\
\text { Holding }\end{array}$} & Alpha & 70.32959 & $\begin{array}{c}4.450 \\
(0.000)\end{array}$ & 10.733 & \multirow{2}{*}{$45.38 \%$} \\
\hline & & Beta & -0.54907 & $\begin{array}{c}-1.854 \\
(0.0638)\end{array}$ & $(0.000)$ & \\
\hline \multirow[t]{2}{*}{$\begin{array}{c}\text { Random Effect } \\
\text { Model }\end{array}$} & \multirow{2}{*}{$\begin{array}{l}\text { Non Promoters } \\
\text { Institutional Holding }\end{array}$} & Alpha & 38.81572 & $\begin{array}{c}39.9 \\
(0.0001)\end{array}$ & .0394 & \multirow{2}{*}{$45.24 \%$} \\
\hline & & Beta & 0.090475 & $\begin{array}{l}.0495 \\
(.8426)\end{array}$ & $(.8425$ & \\
\hline \multirow[t]{2}{*}{ Fixed Effect Model } & \multirow{2}{*}{$\begin{array}{l}\text { Non Promoters Non } \\
\text { Institutional Holding }\end{array}$} & Alpha & 57.53171 & $\begin{array}{c}7.962 \\
(0.000)\end{array}$ & 10.772 & \multirow{2}{*}{$-.0184 \%$} \\
\hline & & Beta & -0.64424 & $\begin{array}{c}-2.359 \\
(0.0184) \\
\end{array}$ & $(0.000)$ & \\
\hline
\end{tabular}

The results indicate that the probability value of t-statistic in case of non-promoters non institutional holding is found to be significant. Hence it can be concluded that the non-promoters non institutional holding have a significant impact on EPS of the firm. In case of promoters holding, non-promoters holding and non-promoters institutional holding no effect is found on EPS of the firm.

The fixed effect model is applied with ROI as dependent variable and non-promoter institutional holding as ownership structure in the firms as independent variable. However random effect model is applied in case of promoters holding, non-promoter holding and non-promoter non institutional holding. The result of the panel regression model is shown below in table.

Table 12. Impact of ownership structures of the firms on ROI

\begin{tabular}{|c|c|c|c|c|c|c|}
\hline \multirow[t]{2}{*}{ Panel regression model } & \multirow{2}{*}{ Independent variable } & \multirow{2}{*}{\multicolumn{2}{|c|}{ Regression coefficients }} & \multirow{2}{*}{$\frac{\text { T statistics }}{\text { (p value) }}$} & \multirow{2}{*}{$\frac{\text { F statistics }}{\text { (p value) }}$} & \multirow[t]{2}{*}{$\mathrm{R}$ square } \\
\hline & & & & & & \\
\hline \multirow[t]{3}{*}{ Random Effect Model } & \multirow{3}{*}{ Promoters Holding } & Intercept & 14.421 & 4.473 & 5.599 & \multirow{3}{*}{$.41 \%$} \\
\hline & & Alpha & & $(0.000)$ & $(0.0181)$ & \\
\hline & & Beta & -.0896 & $\begin{array}{c}2.363 \\
(0.0182)\end{array}$ & & \\
\hline \multirow[t]{3}{*}{ Random Effect Model } & \multirow{3}{*}{ Non Promoters Holding } & Alpha & 25.45 & 7.64 & 2.555 & \multirow{3}{*}{$.18 \%$} \\
\hline & & & & $(0.000)$ & $(.110)$ & \\
\hline & & Beta & -0.04925 & $\begin{array}{c}-1.598 \\
(0.1102)\end{array}$ & & \\
\hline \multirow[t]{2}{*}{ Fixed Effect Model } & \multirow{2}{*}{$\begin{array}{c}\text { Non Promoters } \\
\text { Institutional Holding }\end{array}$} & Alpha & & $\begin{array}{c}7.308 \\
(0.000)\end{array}$ & $\begin{array}{c}8.205 \\
(0.000)\end{array}$ & \multirow{2}{*}{$38.80 \%$} \\
\hline & & Beta & 0.258351 & $\begin{array}{c}3.9840 \\
(0.0001)\end{array}$ & & \\
\hline \multirow[t]{3}{*}{ Random Effect Model } & & Alnha & 26.362 & 12.392 & 14.118 & \multirow{3}{*}{$1.0 \%$} \\
\hline & Non Promoters Non & Aipna & & $(0.000)$ & $(0.0001)$ & \\
\hline & Institutional Holding & Beta & -.2242 & $\begin{array}{c}-3.756 \\
(0.0002) \\
\end{array}$ & & \\
\hline
\end{tabular}

The results indicate that the probability value of t-statistic in case of promoters holding, non-promoters institutional holding and non-promoters non institutional holding is found to be significant. Hence it can be 
concluded that the promoters holding, non-promoters institutional holding and non-promoters non institutional holding have a significant impact on ROI of the firm. In case of non-promoters holding (as an individual variable) no effect is found on ROI of the firm.

In order to analyze the impact of ownership in the selected companies on PAT of the firms, the random effect model is applied. In the analysis the PAT is considered as dependent variable however the different types of ownership structures are considered as independent variables. The result of the panel regression model is shown below in Table 13 .

Table 13. Impact of ownership structures of the firms on PAT

\begin{tabular}{|c|c|c|c|c|c|c|}
\hline \multirow[t]{2}{*}{ Panel regression model } & \multirow{2}{*}{ Independent variable } & \multirow{2}{*}{\multicolumn{2}{|c|}{ Regression coefficients }} & T statistics & F statistics & \multirow{2}{*}{$\mathrm{R}$ square } \\
\hline & & & & (p value) & (p value) & \\
\hline \multirow[t]{4}{*}{ Random Effect Model } & \multirow{4}{*}{ Promoters Holding } & & 114835 & 3.481 & .6456 & \multirow{4}{*}{$.0483 \%$} \\
\hline & & Intercept AIpna & 1148.35 & $(0.0005)$ & $(0.4218)$ & \\
\hline & & Beta & -4251 & -.8036 & & \\
\hline & & Beta & -4.251 & $(0.4217)$ & & \\
\hline \multirow[t]{4}{*}{ Random Effect Model } & \multirow{4}{*}{$\begin{array}{l}\text { Non Promoters } \\
\text { Holding }\end{array}$} & \multirow{2}{*}{ Alpha } & \multirow{2}{*}{1858.18} & 5.761 & 14.187 & \multirow{4}{*}{$1 \%$} \\
\hline & & & & $(0.000)$ & $(0.00017)$ & \\
\hline & & \multirow{2}{*}{ Beta } & \multirow{2}{*}{-17.125} & -3.765 & & \\
\hline & & & & $(0.002)$ & & \\
\hline \multirow[t]{3}{*}{ Random Effect Model } & \multirow{3}{*}{$\begin{array}{c}\text { Non Promoters } \\
\text { Institutional Holding }\end{array}$} & \multirow{2}{*}{ Alpha } & \multirow{2}{*}{894.05} & 3.625 & .2399 & \multirow{3}{*}{$.172 \%$} \\
\hline & & & & $(0.0003)$ & $(.6242)$ & \\
\hline & & Beta & 2.123 & $\begin{array}{c}.4896 \\
(0.6244)\end{array}$ & & \\
\hline \multirow[t]{3}{*}{ Random Effect Model } & \multirow{3}{*}{$\begin{array}{l}\text { Non Promoters Non } \\
\text { Institutional Holding }\end{array}$} & \multirow{2}{*}{ Alpha } & \multirow{2}{*}{1718.4} & 7.252 & 49.30 & \multirow{3}{*}{$3.41 \%$} \\
\hline & & & & $(0.000)$ & $(0.000)$ & \\
\hline & & Beta & -30.386 & $\begin{array}{l}-7.019 \\
(0.000)\end{array}$ & & \\
\hline
\end{tabular}

The results indicate that the probability value of t-statistic in case of non-promoters holding and non-promoters non-institutional holding is found to be significant. Hence it can be concluded that the non-promoters holding and non-promoters non institutional holding have a significant impact on PAT of the firm. In case of promoters holding and non-promoter institutional holding no effect is found on PAT of the firm.

\section{Conclusion}

This research showed that total overall ownership does not explain firm performance. Each aspect needs to be analyzed individually. The differing results in this study are due to the fact that PAT and ROI are two diverse aspects of assessing the profitability, one correlates profit with sales and another with investment. While as EPS is the monetary value of earnings per outstanding share. We also found presence of concentrated ownership in Indian firms. Dispersed ownership or we can say retail ownership impacts all the three dimensions of profitability i.e., EPS, ROI and PAT in this study which goes with the findings of Srivastava (2011). It is found that promoter holding is having significant impact only in case of ROI, the reason for this could be the nature of investment. While calculating EPS, outstanding shares is used as denominator and in case of ROI there can be other dimensions also i.e., ROI can be calculated on capital employed or on net worth also. As far as retail investors in India are concerned, 42 percent of the firms are found to have an average retail holding between 20 $30 \%$ and 28 percent of the firms are found to have an average holding between $30-50 \%$ of retail investors and results in this regard are found to be significant. It indicates that investors in India can influence market to some extent.

The literature on international corporate governance tells us much about ownership structure but the message in the information is far from clear or complete. Much more work remains to be done. Suggestions for further research include the development and estimation of a generalized non-linear model specification and a proper study on impact of ownership structure on dividend policy, market efficiency can be done.

\section{References}

Agrawal, A., \& Knoeber, C. R. (1996). Firm Performance and Mechanisms to Control Agency Problems between Managers and Shareholders. Journal of Financial and Quantitative Analysis, 31(3), 377. 
http://dx.doi.org/10.2307/2331397

Benjamin, B., \& Dirk, C. (2015). Ownership Concentration, Institutional Development and Firm Performance in Central and Eastern Europe. Managerial and Decision Economics.

Berle, A., \& Means, G. (1932). The Modern Corporation and Private Property. New York: Harcourt, Brace, \& World.

Cho, M. H. (1998). Ownership Structure, Investment, and the Corporate Value: An Empirical Analysis. Journal of Financial Economics, 47(1), 103-121. http://dx.doi.org/10.1016/S0304-405X(97)00039-1

Claessens, S., Djankov, S., Fan, J. P. H., \& Lang, L. H. P. (2002). Disentangling the Incentive and Entrenchment Effects of Large Shareholdings. The Journal of Finance, 57(6), 27-41. http://dx.doi.org/10.1111/1540-6261.00511

Cui, H., \& Mak, Y. T. (2002). The relationship between managerial ownership and firm performance in high R\&D firms. Journal of Corporate Finance, 8(4), 313. http://dx.doi.org/10.1016/S0929-1199(01)00047-5

Demsetz, H. (1983). The Structure of Ownership and the Theory of the Firm. Journal of Law and Economics. 26(2), 375-390. http://dx.doi.org/10.1086/467041

Demsetz, H., \& Lehn, K. (1985). The Structure of Corporate Ownership: Causes and Consequences. Journal of Political Economy, 93(6), 1155-1177. http://dx.doi.org/10.1086/261354

Demsetz, H., \& Villalonga, B. (2001). Ownership Structure and Corporate Performance. Journal of Corporate Finance, 7(3), 209-233. http://dx.doi.org/10.1016/S0929-1199(01)00020-7

Dyck, A., \& Zingales, L. (2004). Private Benefits of Control: An International Comparison. The Journal of Finance, 59(2), 537. http://dx.doi.org/10.1111/j.1540-6261.2004.00642.x

Ersoy, H. (2015). The Relationship between Corporate Performance and Ownership Structure: Evidence from Turkey. Emerging Markets Journal, 5(2). http://dx.doi.org/10.5195/emaj.2015.75

Graham, J. R., Campbell, R. H., \& Rajgopal, S. (2005). The economic implications of corporate financial reporting. Journal of Accounting and Economics, 40, 3-73. http://dx.doi.org/10.1016/j.jacceco.2005.01.002

Hindley, B. (1970). Separation of Ownership and Control in the Modern Corporation. Journal of Law and Economics, 13(1), 185. http://dx.doi.org/10.1086/466687

Joh, S. W. (2003). Corporate governance and firm profitability: Evidence from Korea before the economic crisis. Journal of Financial Economics, 68, 287-322. http://dx.doi.org/10.1016/S0304-405X(03)00068-0

Kapopoulas, P., \& Lazaretou, S. (2007). Corporate Ownership Structure and Firm Performance: Evidence from Greek Firms. Corporate Governance: An International Review, 15(2), 144-158. http://dx.doi.org/10.1111/j.1467-8683.2007.00551.x

Kumar, J. (2004). Does Corporate Governance Influence Firm Value? Evidence from Indian Firms. Journal of Entrepreneurial Finance and Business Ventures, 9(2), 61-92.

Lauterbach, B., \& Vaninsky, A. (1999). Ownership Structure and Firm Performance: Evidence from Israel. Journal of Management and Governance, 3, 189-201. http://dx.doi.org/10.1023/A:1009990008724

Loderer, C., \& Martin, K. (1997). Executive Stock Ownership and Performance Tracking Faint Traces. Journal of Financial Economics, 45(2), 595-612. http://dx.doi.org/10.1016/S0304-405X(97)00017-2

Mei, Y. (2013). State ownership and firm performance: Empirical evidence from Chinese listed companies. China Journal of Accounting Research, 6(2), 75-87. http://dx.doi.org/10.1016/j.cjar.2013.03.003

Michael, R. K., \& Eric, S. (2008). Family values: Ownership structure, performance and capital structure of Canadian firms. Journal of Banking \& Finance, 32(11), 2423-2432.

Mohamed, B. (2009). Board structure, ownership structure and firm performance: Evidence from banking. Applied Financial Economics, 19. http://dx.doi.org/10.1080/09603100902967561

Morck, R., Shleifer, A., \& Vishny, R. (1988). Management Ownership and Market Valuation: An Empirical Analysis. Journal of Financial Economics, 20, 293-315. http://dx.doi.org/10.1016/0304-405X(88)90048-7

Pedersen, T., \& Thomsen, S. (1999). Economic and Systemic Explanations of Ownership Concentration among Europe's Largest Companies. International Journal of the Economics of Business, 6(3), 367. http://dx.doi.org/10.1080/13571519984133

Porta, R. L., Lopez-de-Silanes, F., \& Shleifer, A. (1999). Corporate Ownership Around the World. Journal of 
Finance, 54(2), 471-517. http://dx.doi.org/10.1111/0022-1082.00115

Porta, R. L., Lopez-De-Silanes, F., Shleifer, A., \& Vishny, R. W. (1997). Legal Determinants of External Finance. The Journal of Finance, 52(3), 1131. http://dx.doi.org/10.1111/j.1540-6261.1997.tb02727.x

Porta, R. L., Lopez-de-Silanes, F., Shleifer, A., \& Vishny, R. W. (1998). Law and Finance. Journal of Political Economy, 106(6), 1113. http://dx.doi.org/10.1086/250042

Porta, R. L., Lopez-de-Silanes, F., Shleifer, A., \& Vishny, R. W. (2000). Agency Problems and Dividend Policies around the World. The Journal of Finance, 55(1).

Shleifer, A., \& Vishny, R. W. (1986). Large shareholders and corporate control. Journal of Political Economy, 94(3), 461-488. http://dx.doi.org/10.1086/261385

Smith, A. (1776). An Inquiry into the Nature and Causes of the Wealth of Nations. http://dx.doi.org/10.1093/oseo/instance.00043218

Srivastava, A. (2011). Ownership Structure and Corporate Performance: Evidence from India. International Journal of Humanities and Social Science, $l(1)$.

Welch, E. (2003). The Relation Between Ownership Structure and Performance in Listed Australian Companies. Australian Journal of Management, 28(3), 287-305. http://dx.doi.org/10.1177/031289620302800304

Williamson, O. E. (1964). The Economics of Discretionary Behavior: Managerial Objectives in a Theory of the Firm. Prentice-Hall.

\section{Copyrights}

Copyright for this article is retained by the author(s), with first publication rights granted to the journal.

This is an open-access article distributed under the terms and conditions of the Creative Commons Attribution license (http://creativecommons.org/licenses/by/3.0/). 